\title{
TERROR IN EUROPE AND ITS SOURCES IN ILLEGAL MIGRATION FROM THE SOUTH. HOW TO DISTINGUISH ONE FROM THE OTHER AND CONTAIN BOTH
}

\begin{abstract}
:
Currently, Europe has to face new risks and threats, including terrorist attacks, illegal migration, and hybrid warfare that transcend the common security aspects and have further roots beyond its borders, in unsolved hot spot areas, like Eastern and Southern neighbourhood. Today rapid developments in the political and economic fields made terrorism a common problem for all the countries in the world. This is also true for European countries because, with the Madrid bombing of the Atocha Rail Station, where, for the first time in the history of terrorism, two organizations were involved together (Al Qaida and ETA) in committing a violent action, we can speak about the internationalisation of terror and the shift of its political objectives towards those nations supporting the United States in the International War on Terror. Since the 2014 Ukrainian crisis and Syrian conflict, including here military actions to counter the Salafi Jihadist militant group and alleged former Al Qaida affiliate in the Islamic State of Iraq and Syria (ISIS), a period of increased Islamic terrorist activity has taken place in Europe, often referred to as the Wave of Terror in Europe. Terrorists employed a wide range of tactics to support implementation of their overall strategies. In Europe, as we saw in the past events, terrorist organisations have mostly been employing old tactics such as bombing, arson, assassination and suicide attack to achieve their goals. The big issue for terror in Europe is the mix of some of these classical acts with new methods including the use of computer devices, driving transportation means against crowds, shooting and stabbing their targets, in order to transmit proposed messages. The European security context forced more and more European states to take "hard" measures for eliminating the danger of those

${ }^{1}$ Col. (Ret.) Crăişor C. Ioniţă, PhD in the Military Science and Intelligence, member of the Romanian Reserve Officer Association (AORR), where he represents AORR at the Interallied Confederation of Reserve Officers (CIOR), a NATO entity. An active teacher at the NATO School Oberammergau, Germany, as well as the Romanian National Defence University "Carol I" from Bucharest. Email: ionitacc@yahoo.com
\end{abstract}


terrorist organizations. A lot of books have been written and many analyses have been made since the 90s. However, the terrorists modify their tactics and weapons according to new conditions. Moreover, they co-operate with each other and gain a more Mafia like characteristic. Even, terrorist organizations and other crime organizations are going faster than the sovereign countries in the field of cooperation. Consequently, the terrorist organizations, instead of being annihilated, gain more power, with every countermeasure.

\section{Keywords:}

International terrorism, Wave of Terror in Europe, radical Islam, Sahel, illegal migration, islamisation of Europe, radicalisation, Salafism, Al Qaida Instruction Booklet, counter-terrorism, anti-terrorism.

\section{Introduction}

Nowadays, the geostrategic situation in Europe is not too brilliant. Moreover, there are important voices mentioning that we are in a new security dilemma, in which new risks and threats have emerged towards the European common security and Euro-Atlantic collective defence. There are numerous facts demonstrating that the conflict physiognomy has evolved, and the old geopolitical tendencies in the area seemed to return. Especially with the Russian Federation coming back among regional powers, with tendencies to regain her status of 'superpower'.

Those tendencies are also influenced by new risks and threats to the European common security, such as: European terrorism; massive illegal migration in Europe; BREXIT; and, last but not least, the new hybrid-type of warfare. European terrorism is not a new phenomenon, disappearing from Europe for almost 40 years. In addition of using old, established tactics - such as: bombing, arson, assassinations and suicide attacks - this new face of terror has developed new methods of spreading panic among European populations, especially in the West. Through ethnic and religious terrorism, cyberterrorism, crowd smashing, shooting and stabbing innocent people, there are sending terror messages to politician and population without clear political objectives.

When we speak about terrorism in Europe, we can think on three distinct periods from the past till present days. The Cold-War Era and the terrorist groups activities in the Western Europe is a very distinct period being characterized by individual actions with limited objectives, as well as statesponsored terrorism. The post-Cold Era sporadic terrorist acts period that took place until the Syrian Crisis and Ukrainian Crisis had few important terrorist actions, but with greater scope and implications. With the Madrid bombing of Atocha Rail Station, where, for the first time in the history of terrorism, two organisations were acting together (Al Qaida and ETA), we can speak about the internationalisation of terror. And finally, a period of increased Islamic 
terrorist activity in Europe, often referred to as 'the Wave of Terror in Europe' that has been taking place since 2014.

The Cold War period, as everybody is aware, was characterised by the indirect confrontation between the two superpowers - USSR and the United States - to achieve world dominance. None of the two superpowers were prepared or willing to conduct military actions against the other, even if they repeatedly tried to achieve supremacy on all continents.

As a secondary issue, the respective period had also an additional aim in Europe of containing Soviet communism in its borders. The rise of the Berlin Wall and the establishment of the Iron Curtin represented some 'soft' approaches of the two superpowers to contain each other. In order not to directly act against the US, Moscow tried different schemes and tactics to destabilise the US Allies in Europe and control its own. One indirect action against Western Europe was the establishment of terrorist groups in many European countries, like: Armata Corsa and the National Liberation Front of Corsica (FLNC) in France; Red Army Faction (RAF) in Germany; the Basque Homeland and Freedom (ETA) in Spain; Red Brigades (BR) in Italy; Irish Republican Army (IRA) and Loyalist Volunteer Force (LVF) in Northern Ireland; Kurdistan Workers Party (PKK) and the Revolutionary People's Liberation Party/Front (DHCP/F) in Turkey; Revolutionary Organization 17 November and Revolutionary People's Struggle (ELA) in Greece ${ }^{2}$. The USSR covertly trained and sustained those terrorist groups, by providing military equipment and armaments, as well as logistic and financial support, asking them to conduct specific terrorist actions to gain Kremlin's political objectives. We should not forget about the bloody war in the Northern Ireland, as well as about kidnappings, arson, hijacking, hostage - taking, assassinations, bombings, or ambushes conducted in France, Italy, Spain or Germany in 1970s1980s.

Amazing, the collapse of the Soviet Union and the distraction of Berlin Wall represented a 'cease-fire' of terrorist activities in Europe and the disintegration of old European terrorist groups. Being either arrested or moving outside Europe to be part of jihadist movements, European terrorists disappeared and very few terror activities took place in Europe in the last decade of the $20^{\text {th }}$ Century and beginning of the $21^{\text {st }}$ one.

The new geostrategic tendencies in the region refer both to replacing the old strategic interest of regional powers to concur territories with that of controlling/influencing events, and to giving up the idea of physical presence to the one-off controlling to influence and, if necessary, interfere. These tendencies have the effect of defusing existing 'frozen conflicts', avoiding, as

${ }^{2}$ G. Chaliand, A. Blin, From 1968 to Radical Islam, [in:] The History of Terrorism. From Antiquity to Al Qaida, ed. G. Chaliand, A. Blin, London 2007, pp. 223-225; see also H. Ozel, Terrorist Tactics and their Destructions - a presentation delivered by the PfP Training Centre-Turkey Mobile Training Team (MTT) at the Romanian PfP Regional Training Centre in Bucharest, 2.04.2003. 
much as possible, direct armed confrontation, changing the need to cause substantial damage to the opponent and minimising them, and acting at the edge of respecting international laws.

This is also about the revival of terrorist activities in Europe with different approaches regarding tactics and political objectives, whilst no terrorist group was established to activate on the old continent. The so-called internationalisation of terrorism, after the Atocha Rail Station bombing in Madrid and the use of Hybrid Warfare tactics by Russia in Europe, as well as the mass migration of Islamic population in Southern and Central Europe seems to be the main causes of the new wave of terror in Western European countries.

Therefore, my article is aimed at analysing the biggest changes that take place in the terrorism syndrome today, underlining some causes of them, as well as efficient counter - measures for dealing with terrorist activities. At the end, I'll try to answer to some important questions, like: What is the difference between the Cold War Era and the current situation regarding terrorist activities in Europe? Is any regional power (like Russia, Iran etc.) indirectly involved in by supporting terrorism? Is terrorism an international, European or national matter?

\section{Terror in Europe and its possible source in Northern Africa}

Most people have a vague idea or impression of what terrorism is. They lack a more precise and truly explanatory definition of the word. This imprecision has been done partly by the modern media. Pick up a newspaper or turn on the television. Someone can find such different acts as the bombing of a building, the assassination of a head of state, the massacre of civilians by a military unit and the poisoning of produce on supermarket shelves described as incidents of terrorism. Indeed, any unacceptable act of violence that is perceived against society is often labelled 'terrorism'.

Other difficulty when we want to define the word of terrorism is that almost all states regard terror actions as freedom and separatist movements or ordinary incidents. These states condemn terror actions but if these actions are consistent with their interests, they either tolerate or support them. It is well-known the statement that: 'One man's terrorist is another man's freedom fighter'.

Brian M. Jenkins, a well-experienced American expert on terrorism and transportation security, mentioned about terrorism as "...being a theatre, because terrorist acts are often deliberately spectacular, designed to rattle and influence a wide audience, beyond the victims of the violence itself" ${ }^{3}$. If we investigate the definition of terrorism, we see that it has more than one definition. For example, the Oxford English Dictionary's definition give us little help, by defining terrorism as "... a policy intended to strike with terror

${ }^{3}$ B. M. Jenkins, International Terrorism: A new kind of warfare, California 1974, p. 4. 
those against whom it is adopted, the employment of methods of intimidation, the fact of terrorizing or condition of being terrorised"4.

Another definition says that terror, as a concept, means 'intimidating', but this intimidating is in great intensity and capable of creating sudden feelings of fear on individuals explaining the manner of violence. In Figure 1 Nicholas Pratt, from the George C. Marshal Center, defines terrorism from a trinity point of view of aim, action and target ${ }^{5}$.

\section{Fig. 1. Defining Terrorism}

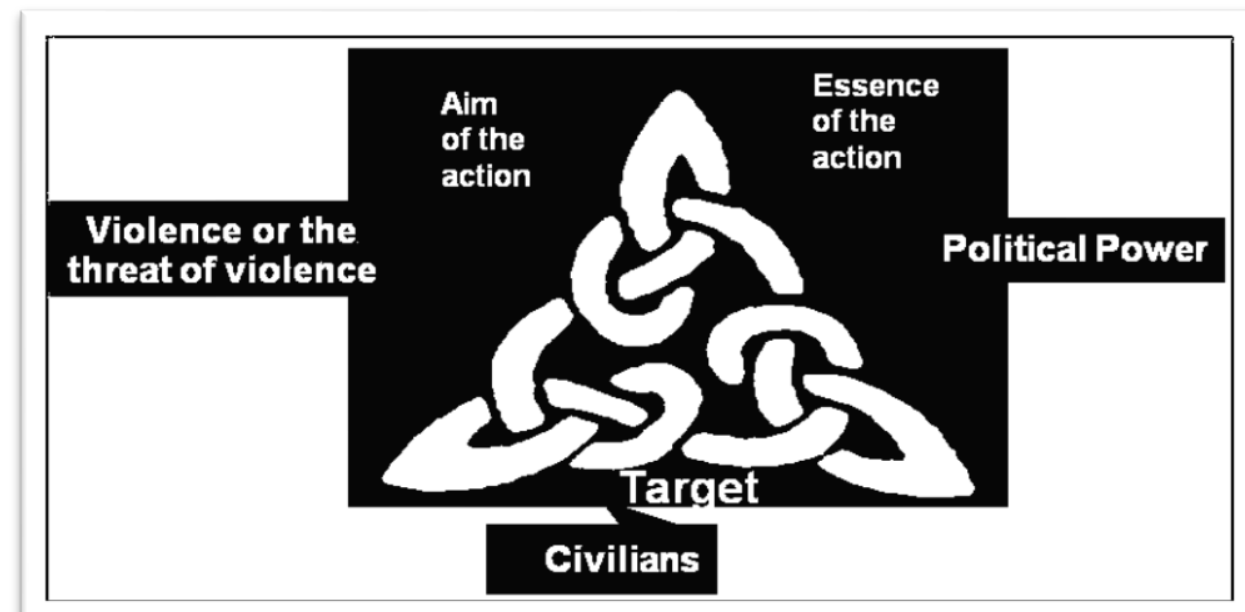

Source: R. Kangas, NATO..., op. cit.

According to AAP-6, NATO's definition on terrorism is "The unlawful use or threatened use of force or violence, instilling fear and terror, against individuals or property in an attempt to coerce or intimidate governments or societies, or to gain control over a population, to achieve political, religious or ideological objectives"

The new "wave of terror in Europe" is often seen as part of the spill over of the Syrian Civil War and linked to the rise of the Islamic State of Iraq and the

${ }^{4}$ Oxford Learner's Dictionaries, Terrorism, <https://www.oxfordlearnersdictionaries.com/ definition/english/terrorism> (11.03.2020).

${ }^{5}$ R. Kangas, Recommended US Response to Russian Activities Across Central Asia, [in:] Russian Strategic Intentions. A Strategic Multilayer Assessment (SMA) White Paper, ed. N. Peterson, Departament of Defence 2019, pp. 99-104; see also R. Kangas, NATO and the Challenge of Terrorism: Expanding the Area of Responsibility, presentation delivered at the George C. Marshall Center in Garmish Partenkirschen, 10.08.2006.

${ }^{6}$ NATO Glossary of Terms and Definitions nr AAP-6 (2019), Terrorism, NATO Standardization Agency, p. 154. 
Levant/Syria (ISIL/ISIS). It has also been linked to the rise of radical Islam among some disaffected Muslims minorities in Europe, and to the European mass migrant crisis.

A captured German ISIS trainee, Harry Sarfo told the New York Times that his commander had said, in mid-2015, that "ISIS had called on its fighters for a coordinated wave of attacks in European countries"7. The majority of the attacks have taken place against countries participating in the Syrian Civil War in the military intervention against ISIS as part of Operation 'Inherent Resolve'; for instance France with Operation 'Chammal', Germany with Operation 'Counter Daesh' and Belgium, which is also a participant. Russia who have a separate campaign and are allied with the Syrian government, have also been targeted. However, even non-combatants such as Sweden have been attacked. While law enforcement officials have been targeted by ISIS militants, the overwhelming majority of the deaths, over 300 to date, have come from indiscriminate attacks against civilian population in dense urban areas. The majority of the victims are European civilians, but also several civilians from Asia, Africa, and the Americas were killed in terrorist attacks. Some of the attacks have been carried out by lone wolf Salafist jihadists, not officially part of ISIS.

The spill over of the Syrian Civil War is the impact of the Syrian Civil War in the Arab World. Since the first protests during the so-called 'Arab Spring', the increasingly violent Syrian Civil War has been both a proxy war for the major Arab powers, Turkey and Iran, and a potential launching point for a wider regional war after the involvement of Russia. Fears of the latter were realised when ISIS, a Salafi Jihadist militant group and alleged former Al Qaida affiliate, established itself in Syria in 2013, and later combined with the Iraqi Civil War into a single conflict the following year. The spill over of the Syrian Civil War is often dubbed as the 'Arab Winter'.

A campaign of Islamist attacks occurred in France, beginning with the Îlede-France attack on 7 January 2015, between the French Government and ongoing terrorist acts committed by jihadist terror groups like AQAP and ISIS, or isolated individuals who sympathize with the jihadist movement. Since 2015 and until July 2016, eight Islamic terrorist incidents have occurred in France, including fatal attacks in Île-de-France, Saint-Quentin-Fallavier and Paris. The November 2015 attacks in Paris were motivated by ISIS as retaliation for the French role in Syrian Civil War and Iraqi War.

There is evidence about the fact that ISIS intended to create momentum behind a campaign of attacks in Europe which requires less direct input from it over time. In 2015, the ISIS goal in Europe was to provoke overreactions by European governments that would alienate Muslim communities and radicalise them over time. ISIS designed a campaign to inject violence into European

S. Osborne, ISIS Commanders call for a coordinated wave of terror attacks in UK, Germany and France, <https://www.express.co.uk/news/world/696404/ISIS-commandersco-ordinated-wave-terror-attacks-UK-Germany-France> (19.08.2019). 
societies in order to jumpstart a campaign of low-level attacks against nonMuslim populations in Europe that would further polarize European communities ${ }^{8}$.

The scope and volume of low-level attacks that fit ISIS's calls for 'lone jihad' in Europe nearly quadrupled in Europe from January 2014 to September 2017. This trend could signal a growing resonance of ISIS's messaging to vulnerable populations despite ISIS's territorial losses in Iraq and Syria. If so, this trend would demonstrate ISIS success generating a campaign of violence in Europe that requires progressively less direct input from ISIS to sustain.

The 2015 conflict between Turkey and the PKK broke out following a twoyear period of long peace negotiations, which began in late 2012, but failed to progress in light of the growing tensions on border with Syria in late 2014, when the Siege of Kobani created an unprecedented wave of Kurdish refugees into Turkey. Some Kurds accused Turkey of assisting ISIS during the crisis, resulting in widespread Kurdish riots in Turkey involving dozens of fatalities. The tensions further escalated in summer 2015, with the 20 July's bombing in Suruc, allegedly executed by an ISIS-affiliated Turkish group against Kurdish supporters. On 21 July, same year, PKK killed a Turkish soldier and wounded two more in Adiyaman. Some PKK supporters then claimed responsibility for the 23 July's killing of two Turkish police officers in Ceylanpinar, describing it as a retaliation to the fact that Turkey was training Islamic State terrorists in a camp disguised as a training ground for the Free Syrian Army. In PKK's opinion, Ankara's help to the 'moderate' Syrian opposition is not as innocent as portrayed and Turkey was perceived more as 'a friend' of Islamic State, than an enemy ${ }^{9}$. The rise of Islamic radicals in Europe is also linked to the new wave of terror. The Islamic extremism was defined by the British High Court as any form of Islam that opposes "democracy, the rule of law, individual liberty and mutual respect and tolerance of different faiths and beliefs" 10 .

Zeyno Baran, a Senior Fellow and Director of the Center for Eurasian Policy at the Hudson Institute, also defined the Islamic extremism, sometimes using overlapping terms that described distinct aspects of extreme interpretations and pursuits of Islamic ideology - "the use of violent tactics such as bombing and assassinations for achieving perceived Islamic goals" and "an extremely conservative view of Islam, which does not necessarily entail violence" $"$.

${ }^{8}$ J. Cafarella, J. Zhou, ISIS's Expanding Campaign in Europe, Washington 2017, p. 3.

${ }^{9}$ Captured ISIS fighter says "trained in Turkey, ISIS thinks it's safer here than Syria", <https://www.rt.com/news/327222-isis-fighters-turkey-training/> (19.08.2019).

${ }^{10} \mathrm{D}$. Casciani, How do you define Islamist extremism? <https://www.bbc.com/news/uk27777892> (20.08.2019).

${ }^{11}$ B. Zeyno, The Roots of Violent Islamist Extremism and Efforts to Counter It, Hearing Before The Committee on Homeland Security and Governmental Affairs United States Senate, One Hundred Tenth Congress Second Session, 10.07.2008, Washington 2009, pp. 119-124, <https://fas.org/irp/congress/2008_hr/roots.pdf> (20.08.2019). 
There is no single profile or pathway for radicalisation, or even speed at which it happens. Nor does the level of education seem to be a reliable predictor of vulnerability to radicalization. It is, however, established that there are socio-economic, psychological and institutional factors that lead to violent extremism. Specialists group these factors into three main categories: push factors, pull factors and contextual factors. 'Push Factors' drive individuals to violent extremism, such as: marginalisation, inequality, discrimination, persecution or the perception thereof; limited access to quality and relevant education; the denial of rights and civil liberties; and other environmental, historical and socio-economic grievances.

'Pull Factors' nurture the appeal of violent extremism, for example: the existence of well-organized violent extremist groups with compelling discourses and effective programmes that are providing services, revenue and/or employment in exchange for membership. Groups can also lure new members by providing outlets for grievances and promise of adventure and freedom. Furthermore, these groups appear to offer spiritual comfort, 'a place to belong' and a supportive social network. Contextual factors are those factors that provide a favourable terrain to the emergence of violent extremist groups, such as: fragile states, the lack of rule of low, corruption and criminality.

The following behaviours, in combination, have been identified as signs of potential radicalisation: sudden break with the family and long-standing friendships; sudden drop-out of school and conflicts with the school; change in behaviour relating to food, clothing, language or finances; changes in attitudes and behaviour towards others: antisocial comments, rejection of authority, refusal to interact socially, signs of withdrawal and isolation; regular viewing of internet sites and participation in social media networks that condone radical or extremist views; and reference to apocalyptic and conspiracy theories. Is it a kind of 'burgeoning wave of terrorism?' asked Gilles Kepel, a leading French expert on fundamentalist Islam, who also claimed that in London or Londonistan as he calls it, "they gave shelter to radical Islamist leaders from around the world as a sort of insurance policy against jihad terrorism. But you know when you go for dinner with the devil..." 12 .

As a general conclusion, some of the proponents of Islam emphasised peaceful political processes, whereas Sayyid Outb in particular called for violence, and those followers are generally considered Islamic extremists and their stated goal is Islamic revolution with the intent to force implementation of Sharia law and/or an Islamic State Caliphate.

The European migrant crisis, or the European refugee crisis, another potential event linked with the new wave of terror, began in 2015 when rising numbers of people arrived illegally in the EU, travelling across the Mediterranean Sea or overland through Southeast Europe. These people included not only asylees seeking to apply for refugee status and the right of

${ }^{12}$ G. Kepel, Terror in France: The Rise of Jihad in the West, Cambridge 2002, p. 54. 
asylum in claims to be individually determined as genuine or not, but also encompassed various others, such as economic migrants, and a small number of hostile agents including 'Islamic State militants' .

In January 2016, 18 of 31 men suspected of violent assaults on women in Cologne on New Year's Eve were identified as asylum seekers, prompting calls by German officials to deport convicted criminals who may be seeking asylum; these sexual attacks brought about a fresh wave of anti-immigrant protest across Europe. The message presented by Geert Wilders, the President of the Dutch Freedom Party and member of the Dutch Parliament, in front of the US Congress on 29 September 2015 represented, in fact, the official recognition of the Islamisation of Europe. He made a clear statement when he mentioned that: "We are in the final phase of the Islamisation of Europe. This is not a current and transparent danger for the future of Europe itself, but also for America and the entire survivability of the West"13.

According to an IOM official, a rise in arrivals in Italy since the beginning of 2016 can be explained by a growing number of migrants from sub-Saharan Africa, in particular from Nigeria, Gambia and Mali. The number of migrants from Morocco has also been on the rise, with 483 arriving in January 2016 against 93 in January 2015.

According to UNHCR, almost $22 \%$ of the refugees that managed to cross the Mediterranean Sea were from Northern and Sub-Saharian part of Africa. $4 \%$ of them were coming from Eritrea. Other countries include Nigeria (2\%), Somalia (2\%), Sudan (1\%), Gambia (1\%), Mali (1\%), Senegal, and Morocco ${ }^{14}$.

It is worthwhile mentioning here the rise of Salafism in Europe as a potential link to the terrorism on the old continent. It is not about the political Salafism, which directs its recruitment efforts towards non-Muslims and nonSalafist Muslims to gain influence in society. Here, we discuss about the jihadist Salafism, a minority movement in Europe that advocates gaining influence by the use of violence and nearly all identified terrorist cells in Germany and France came from Salafist circles.

\section{Main Causes and Objectives for Terrorist Acts}

From the violent actions been undertaken after 2010, we can state that the new terror in Europe has an international character and is conducted/organised by International terrorist groups having their location in Middle East and Africa/Sahel. In fact, what happened in Europe represents the abroad extension of terrorist groups' activities in their respective country/region, having the possibility (means, support, state-sponsored) to act oversees.

${ }^{13}$ Speech Geert Wilders for US Congressmen, Washington DC, Conservative Opportunity Society, 29.04.2015, <https://www.geertwilders.nl/94-english/1921-speech-us-congressman-29042015> (23.06.2018).

${ }_{14}$ Migration to Europe in charts, <https://www.bbc.com/news/world-europe-44660699> (17.07.2019). 
Why Europe? Because the US is very well protected and difficult to be internally hit. What happened in 2001 with the World Trade Centre will never be repeated, ever. And the European interest and implications in the conflicts happening in the Middle East and Africa are not well received by belligerents.

Moreover, without financial and logistic support, terrorist groups like alQaeda or ISIS cannot operate in other regions of the World. And this is true if we remember the Madrid Bombing of Atocha Rail Station of 2004. Without ETA logistic support that attack couldn't ever happen. In fact, that specific terrorist act represents the internationalisation of terrorism. The Figure 2 presents an analysis of such internationalisation of terror, through a network of networks.

Fig. 2. International Terrorism: a Network of Networks

\section{International Terrorism:}

\section{A Network of Networks}

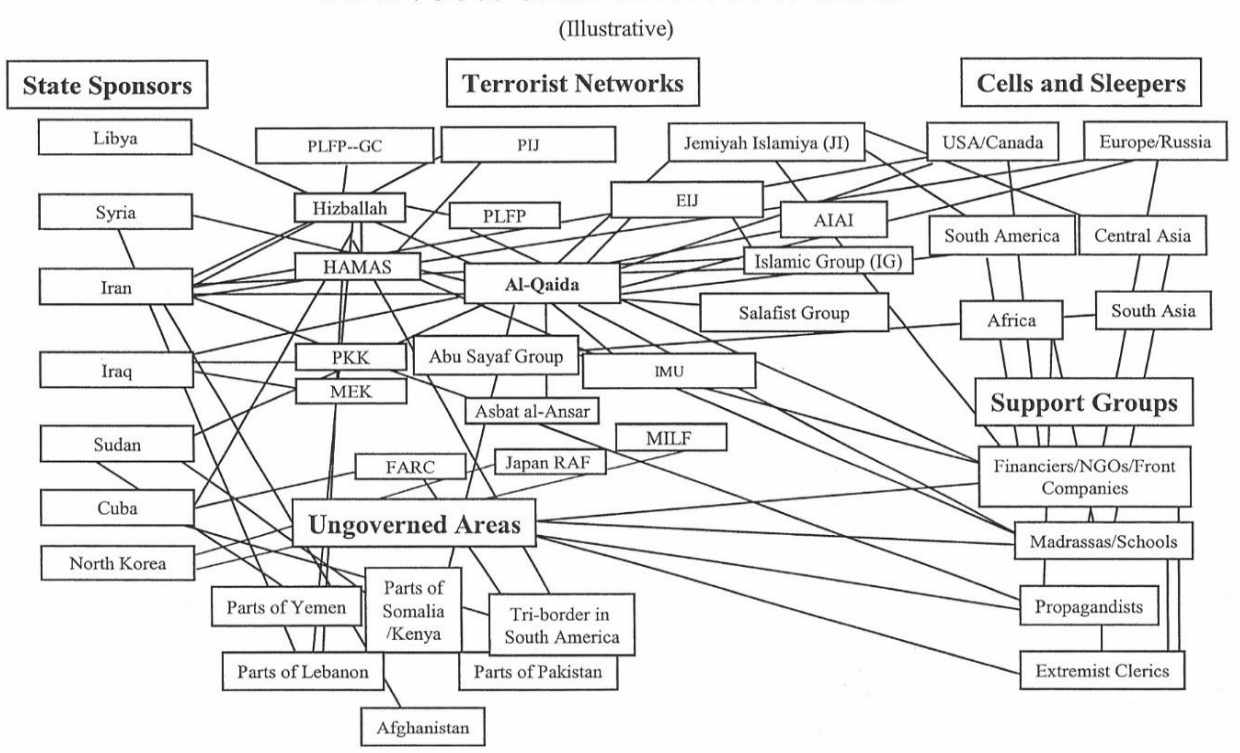

Source: R. Kangas, NATO..., op. cit.

On any single day, acts of terrorism take place around the world for a variety of motives. Whether the terrorists style themselves as separatists, anarchists, dissidents, nationalist, what marks them as terrorists is that they direct their violence against non-combatants, with the goal of terrorising a wider audience than the immediate victims, thereby attempting to gain political influence over the larger audience. It is assumed that many reasons involve with the cause of terrorism but only a few will be analysed here. 
The first and upmost important cause is represented by socio-cultural reasons. Cultural change causes quite a few changes in social life, in other words, social life changes in proportion to cultural changes. However, if these changes in social structure are much too fast and take place only in a certain section of the society, making the rest remain undeveloped and fall far behind, problems occur and social balance is not maintained any longer. Consequently, conflicts among the people in society forms of course, it is impossible that every people think in the same way. Yet, there should be common agreements on some subjects for the good of society itself. These abnormalities mostly occur to be anarchy, violence, and losing social identity and unity. Actually, the ones in favour of violence and anarchy bring the individuals who constitute the society into the dilemmas of what is right or wrong causing confusion on the concepts regarding culture, language, religion, morality, and family. Therefore, they form an atmosphere to impose their claims and ideologies.

The economic reasons represent the second most important cause of terrorism. Economical problems affect people not only materially but also psychologically. That is why, the unbalanced sharing of income in the society is one of the most important elements terror organisations make use of. This is used as a material of propaganda and a tool for exploitation. Consequently, uneducated and ignorant people are very subject to be manipulated.

Many positive consequences, fast developments in the economic and social life can lead to inharmonious and unstable effects on a group of young people in their sensitive period. The lack or insufficiency of basic institutions dealing with such problems among young people is unfortunately enhance the inharmonious manners. System may not work right if economic development and growth are not supported with social integration.

Educational reasons are also important to note. Education has the power of changing the thoughts of individuals and society thoroughly. There is an opportunity to make people even as it is always missed and expected through a good education.

The peace of societies depends on completely proved and affirmative education, which its members get. Briefly, the better and the more sufficient and affirmative the education is, the more useful individuals the society has, or the other way round. The role and duty of families, schools, institutions and media is to make people have decent characters leading them to serve the society, and the role of the government is to make this education possible supervising and controlling it at the same time.

The aim of the new wave of terror seems to be destroying the European political support gained by some local authorities/belligerents in different conflicts from the Middle East and Africa in the long run. Nevertheless, there should be some other aims in the short run. It is possible to summarise these short run targets as follows: destruction of the politic system in European states and weakening the existing Regional organizations, like the EU; letting the European public hear their claim; weakening the European public's power of 
resistance with the help of intimidating people and forcing the people accept their case or take measures against state authorities; providing the support of people and participants in the society

Regarding the strategies terrorists use in achieving their goals, we can mention the tendency of forming an atmosphere of despair, fear and destruction among the groups determined as targets. If the psychological consequences of an activity of violence are more influential and affective than the physical destruction, it is explained as terrorism.

Moreover, terrorists never recognise any morality or rules of war. In their point of view, nobody can be neutral, that is, a person should be in favour of them or stand on the opposite side as an enemy. Therefore, they use brutal, barbarian methods and weapons, without any discrepancies.

The common strategy of the terrorism is to commit acts of violence that will draw the attention of people, the government, and world to their plight. The media play a critical role in this strategy. This is particularly true of terrorism in Europe, where terrorist groups have become increasingly more violent and spectacular in order to capture headlines. Victims of terrorism are seldom the actual targets of the terrorist attack. The target is more often the general public or perhaps even the business sector. By threatening, or carrying out acts of extreme violence against a victim, the terrorist is attempting to produce fear in the victim and in the target, who are both dependent on the government for protection.

Simultaneously, terrorist groups, actually or tacitly, makes demands on the government which in return, must react in some way to the terrorist, the target, and the victim. Violence or the threat of violence on the part of terrorists creates fear in victims and, through the media, fear in the target group or population. This fear generates dependence, on the part of victim and target, on government protection. Terrorist rhetoric and demands placed on government further aggravate this complex set of relationships. Terrorists employ a wide range of tactics to support implementation of their overall strategies.

In Europe, as you're all aware, terrorist organisations have mostly been employing old tactics such as bombing, arson, assassination and suicide attack to achieve their goals. The big issue for terror in Europe is the mix of some of these classical acts with new methods including the use of computer devices, driving transportation means against crowds, shooting and stabbing their targets, in order to transmit proposed messages.

\section{Combating Terrorism Measures or Containing its Sources}

It is very difficult for a single country, being well-developed or modernised, like France or Germany, to face, by her own, multiple terrorist attacks, some of them being conducted simultaneously and concentrated upon well-established target groups and objectives. Therefore, a combined reaction/counter-action of international and regional security organisations (the UN, NATO and the EU), 
together with European countries involved, represents the most effective way to break the new wave of terror.

The International Community (UN and other regional organizations) up to date created 19 conventions - 12 of them are UN ones - on different aspects of the international terrorism. Amongst these conventions the most important are: The International Convention for the Suppression of Terrorist Bombings, New York, signed on 15 December 1997; The International Convention for the Suppression of the Financing of Terrorism, New York, approved on 9 December 1999; and The UNSC Resolution No. 1373, which approved the establishment of the Counter-Terrorism Committee (known as CTC), made up of all 15 members of the Security Council, to increase capability of states to fight terrorism.

Also, according to the Resolution no 56/261, the General Assembly adopted counter-terrorism programmes for implementing the Vienna Declaration on Crime and Justice, many of them dealing with public awareness, maintaining existing databases, collecting and disseminating information and strengthening the capacity of States to face terrorist activities.

In particular, the most important UN activity was to prevent radicalisation and conduct deradicalisation where it happened, through education, as key dimensions of preventing violent extremism. The role of education in preventing violent extremism and de-radicalizing young people has only recently gained global acceptance. An important step in this direction was the launch, in December 2015, of the UN Secretary General's Plan of Action to Prevent Violent Extremism which recognizes the importance of quality education to address the drivers of this phenomenon. Education has been identified as preventing radicalisation through: developing the communication and interpersonal skills they need to dialogue, face disagreement and learn peaceful approaches to change; developing critical thinking to investigate claims, verify rumours and question the legitimacy and appeal of extremist beliefs; developing resilience to resist extremist narratives and acquire the social-emotional skills they need to overcome their doubts and engage constructively in society without having to resort to violence; fostering critically informed citizens able to constructively engage in peaceful collective action.

The UNSC also emphasised this point in its Resolutions $\mathrm{nr} 2178$ and $\mathrm{nr}$ 2250 , which notably highlights the need for "quality education for peace that equips youth with the ability to engage constructively in civic structures and inclusive political processes" and called on "all relevant actors to consider instituting mechanisms to promote a culture of peace, tolerance, intercultural 
and interreligious dialogue that involve youth and discourage their participation in acts of violence, terrorism, xenophobia, and all forms of discrimination" ${ }^{\text {" }}$.

UNESCO has emphasised the Global Citizenship Education (GCED) programme as an emerging approach to education that focuses on developing learners' knowledge, skills, values and attitudes in view of their active participation in the peaceful and sustainable development of their societies. GCED aimed to instil respect for human rights, social justice, gender equality and environmental sustainability, which are fundamental values that help raise the defences of peace against violent extremism.

In order to possible deradicalise existing islamists all over the World, there have been initiated and operationalized several projects inside the UN. The Sabaoon Project is one of them and was initiated by the Pakistan Army and run by the Social Welfare Academics and Training organisation (SWAaT) since 2009 , to deradicalise and rehabilitate former militant youth who were involved in violent extremist activities and apprehended by the army in SWAaT and the surrounding areas in Pakistan.

Kenya's initiatives to address radicalisation of youth in educational institutions is another project to tackle the issue of violent extremism and radicalisation in schools. It represented a Kenyan Ministry of Education, Science and Technology's new national strategy of targeting youth in 2014, entitled Initiatives to Address Radicalization of the Youth in Educational Institutions in the Republic of Kenya. The Strategy adopted measures that service the students' interests and well-being (for example, it includes efforts to create child-friendly school environments) and encouraged students to participate in 'talent academies' to pursue an area of their own interest. The Strategy also included the discontinuation of ranking schools based on academic performance. This was to lessen the over-emphasis on examinations and to reduce student pressure, incorporating other indicators of student achievement, such as abilities in sport and artistic talent. The purpose was to reduce the stress of students' lives at home and in school that may be vented through escape tactics, including joining outlawed groups. The Strategy also employed other effective means to prevent violent extremism, including the integration of Preventing of Violent Extremism through Education (PVE-E) in curricula and school programmes; adopting a multi-sectoral and multistakeholder approach; encouraging student participation through student governance processes and peer-to-peer education; and the involvement of media as a stakeholder.

Another measure adopted by the UN was regarding the Gender disparity. Violent extremism was considered, indisputably, a gendered phenomenon. Indeed, while it was being increasingly reported that women played an active

${ }^{15}$ Security Council, Unanimously Adopting Resolution 2250 (2015), Urges Member States to Increase Representation of Youth in Decision-Making at All Levels, Security Council Statement on 9.12.2015, <https://www.un.org/press/en/2015/sc12149.doc.htm> (20.08.2019). 
role in violent extremist organisations and attacks as assailants and supporters, men are still more often the perpetrators of violent extremist acts and therefore the targets of recruitment campaigns.

After the 2001 terrorist attacks against the US, NATO declared the attacks to be an attack against all NATO member countries. The Allies - for the first time in NATO's history - invoked article 5 of the Washington Treaty and two operations were simultaneously conducted - one Air Operation Eagle Assist in the US and one Maritime Operations Active Endeavour in the Mediterranean Sea. While NATO's contribution to the fight against terrorism has already been significant, efforts were undertaken to better equip the Alliance and to allow it to play its full part in the long-term effort. At the Prague Summit (21-22 November, 2002) was adopted a package of measures to strengthen NATO's preparedness and ability to take on the full spectrum of security challenges, including terrorism and the spread of WMD.

A new NATO military concept for defence against terrorism was developed in order to underline the Alliance's readiness to: act against terrorist attacks, or the threat of such attacks, directed from abroad against populations, territory, infrastructure and forces; provide assistance to national authorities in dealing with the consequences of terrorist attacks; support operations by the EU or other international organisations or coalitions involving Allies; and to deploy forces as and where required to carry out such missions.

After 2014, NATO adopted new measures to counter the new threat on terror in Europe thorough: defence against WMD; a Partnership Action Plan on Terrorism (PARP-T); protection on civilian populations; Missile Defence; Cyberdefence; and cooperation with other international organisations - NATO Support to the AU.

Defining terrorism as one of the most serious violations of fundamental freedoms, human rights and of the principles of liberty and democracy, the EU has first raised this issue at the Tampere European Council in 1999 and again at the Santa Maria da Feira European Council in June 2000, finalising it with the approval of the Council Framework Decision of 13 Jun 2002 on combating terrorism. This Framework Decision defines a terrorist group as "a structured organisation consisting of more than two persons, established over a period of time and acting in concert. Moreover, instigating, aiding, abetting and attempting to commit terrorist offences will also be punishable"16. It also includes some recommended measures, like: provisions in the national legislation for such acts; establishing jurisdiction of Member States; and assistance for victims and their families

The EU supports the Sahel countries - Burkina Faso, Chad, Mali, Mauritania, Niger - in issues of shared interest such as: Security, Migration,

${ }^{16}$ Council Framework Decision of 13 Jun 2002 on combating terrorism, Eur-Lex. Access to European Union Law, <https://eur-lex.europa.eu/legal-content/GA/TXT/> (20.08.2019). 
Terrorism, the Humanitarian situation and Long Term Development ${ }^{17}$. Therefore, in March 2011, the EU adopted a comprehensive approach to the Sahel region, using as reference an EU Strategy for Security and Development (Sahel Strategy). This Strategy remains the key framework for EU action at both individual and collective levels to help countries in the wider Sahel-Sahara region address key security and development challenges.

In March 2014, EU Foreign Affairs extended the Strategy to Burkina Faso and Chad in addition to Mali, Mauritania and Niger. Ministers also asked for the development of a new Regional Action Plan for the implementation of the EU Strategy for Security and Development in the Sahel. The Action Plan was adopted by Ministers of Foreign Affairs on April 202015 and was reviewed and updated beginning of June 2016. With the establishment of this comprehensive framework for EU's action in the Sahel region, the EU reiterates its readiness to continue working closely with the Sahel countries to support their efforts to achieve peace, security and development ${ }^{18}$.

In March 2016, the EU and Turkey reached an agreement to stop irregular immigration through the Aegean Sea, and improve the conditions of more than 3 million Syrian refugees in Turkey. An exchange program that would return migrants that previously entered Europe to Turkey and settle Syrian refugees in EU countries failed to curb the immigrant flow, as the high rate of illegal migrants intercepted by Turkey indicates.

We can state that the EU has failed in adapting its rules and regulations to support the massive wave of immigrants. Moreover, it did not succeed to accommodate Islam extremists inside the Europe's supposed values of enlightenment and humanism. Instead, European countries increased their number of border walls to not allow immigrants to enter on their territories.

Europe had five border walls in 2014, built following the 1985' Schengen agreement amid concerns about immigration at the bloc's external borders. By 2017, it had 15 barriers, according to the not-for-profit Transnational Institute, and a heavily patrolled maritime border. 10 of 28 member states (Spain, Greece, Hungary, Bulgaria, Austria, Slovenia, United Kingdom, Latvia, Estonia and Lithuania) have built walls on their borders to prevent immigration, all of them belonging to the Schengen area except for Bulgaria and the United Kingdom. One country that is not a member of the European Union but belongs to the Schengen area has built a wall to prevent migration (Norway). Another (Slovakia) has built internal walls for racial segregation. A total of 13 walls have been built on EU borders or inside the Schengen area. Two countries, both members of the European Union and the Schengen area, (Spain and Hungary)

${ }^{17}$ Factsheet, EU relations with Sahel countries - Burkina Faso, Chad, Mali, Mauritania, Niger, Brussels 2017, p. 1, <http://eeas.europa.eu/archives/docs/factsheets/docs/saheleuropean-union-factsheet_en.pdf> (21.08.2019).

18 Annual Report on the Sahel Regional Action Plan, Joint Staff Working Document, Brussels, 23.12. 2016, SWD (2016)/482, pp. 4-7, <http://data.consilium.europa.eu/doc/ document/ST-5009-2017-INIT/en/pdf> (20.08.2019). 
have built two walls on their borders for controlling migration. Another two (Austria and the United Kingdom) have built walls on their shared borders with Schengen countries (Slovenia and France respectively). A country outside of the European Union, but part of of the so-called Balkan route (North Macedonia), has built a wall to prevent migration ${ }^{19}$.

The EU has pulled the plug on its naval involvement in the Mediterranean anti-smuggling Operation 'Sophia'. The move showed that the bloc has failed to establish a common policy on refugees.

Between 11 and 12 November 2015, a summit between European and African leaders was held in Valletta, Malta, to discuss the migrant crisis. The summit resulted in the EU setting up an Emergency Trust Fund to promote development in Africa, in return for African countries to help out in the crisis.

At the same time, European states have taken some measures to eliminate the dangers of terrorist organisations. A lot of books have been written and many analyses have been made since the 90 s. However, terrorists modify their tactics and weapons according to new conditions. Moreover, they started to cooperate with each other and gained a more Mafia like characteristic. Even, terrorist groups and other crime organisations are going faster than the sovereign countries in the field of cooperation. Consequently, the terrorist organisations, instead of being annihilated, gained more power, with every counter-measure.

In 2017, Italy struck a deal to supply the Libyan Coast Guard with vessels and anti-smuggling training. The agreement promised 325 million USD if Libyan agents would intercept migrants crossing the Mediterranean and return them to Libyan detention centres. In 2015, Germany broke the Dublin Regulation, a key EU procedure and accepted Syrian refugees fleeing civil war and not return them to border countries that have been accepting unprecedented waves of migrants. Moreover, other EU countries, like Malta and Italy, put pressure on refugee sea rescue missions - the 'criminalisation campaign' against NGO.

A new migration route to Europe was seeing the day - the crossing via the Black Sea, north of Turkey. In less than a month, 500 migrants (Syrians, Iraqis, Afghans and lastly Pakistanis) have been intercepted in Romanian waters in their desperate attempts to reach the European mainland. Human rights activists are trying to warn of the perils involved in the dangerous crossing.

Romania has also received a significant number of asylum seekers through the EU relocation scheme. She agreed to take in around 4,200 asylum seekers. As of the end of August, 727 people had been relocated to Romania - 45 from Italy and 682 from Greece, while another 3,453 must be transferred in accordance with its share. Another 11 people have been resettled from Turkey so far.

${ }^{19}$ G. Diez, The Migrant Crisis and the Future of Europe, The American Prospect, <https://prospect.org/world/migration-crisis-future-europe/> (20.08.2019). 
Migrants generally do not want to stay in Romania, because the country 'doesn't offer them much'. According to the International Organisation for Migration Report, some have had 'tolerated' status for 10 years and "there is no financial support, no doctors help you" ${ }^{20}$.

In conclusion, the World's goal is to eliminate terrorist safe havens, dry up the terrorists sources of revenue, break up their cells, disrupt their movements, bring them to justice for their crimes. It is never easy to stop terrorism but we can reduce the ability of terrorism by taking necessary precautions.

\section{BIBLIOGRAPHY:}

$\checkmark$ Annual Report on the Sahel Regional Action Plan, Joint Staff Working Document, Brussels, 23.12. 2016, SWD (2016)/482, <http://data.consilium.europa.eu/doc/document/ST-5009-2017-INIT/en/pdf>

$\checkmark$ Cafarella J., Zhou J., ISIS's Expanding Campaign in Europe, Washington 2017

$\checkmark$ Captured ISIS fighter says "trained in Turkey, ISIS thinks it's safer here than Syria", <https://www.rt.com/news/327222-isis-fightersturkey-training/>

$\checkmark$ Casciani D., How do you define Islamist extremism? <https://www.bbc.com/news/uk-27777892>

$\checkmark$ Chaliand G., Blin A., From 1968 to Radical Islam, [in:] The History of Terrorism. From Antiquity to Al Qaida, ed. G. Chaliand, A. Blin, London 2007

$\checkmark$ Council Framework Decision of 13 Jun 2002 on combating terrorism, Eur-Lex. Access to European Union Law, <https://eur-lex.europa.eu/legal-content/GA/TXT/>

$\checkmark$ Diez G., The Migrant Crisis and the Future of Europe, The American Prospect, <https://prospect.org/world/migration-crisis-future-europe/>

$\checkmark$ Factsheet, EU relations with Sahel countries - Burkina Faso, Chad, Mali, Mauritania, Niger, Brussels 2017, <http://eeas.europa.eu/ archives/docs/factsheets/docs/sahel-european-union-factsheet_en.pdf $>$

$\checkmark$ Jenkins B. M., International Terrorism: A new kind of warfare, California 1974

$\checkmark$ Kangas R., NATO and the Challenge of Terrorism: Expanding the Area of Responsibility, presentation delivered at the George C. Marshall Center in Garmish Partenkirschen, 10.08. 2006

${ }^{20}$ Mixed Migration Flows in the Mediterranean, Compilation of Available Data and Information, January 2020, International Organization for Migrations, The UN Migration Agency, New York 2019, p. 28, <https://displacement.iom.int/system/tdf/reports/FCR\%20Jan\%202020_final.pdf> (21.08.2019). 
$\checkmark$ Kangas R., Recommended US Response to Russian Activities Across Central Asia, [in:] Russian Strategic Intentions. A Strategic Multilayer Assessment (SMA) White Paper, ed. N. Peterson, Departament of Defence 2019, pp. 99-104

$\checkmark$ Kepel G., Terror in France: The Rise of Jihad in the West, Cambridge 2002

$\checkmark$ Migration to Europe in charts, <https://www.bbc.com/news/worldeurope-44660699>

$\checkmark$ Mixed Migration Flows in the Mediterranean, Compilation of Available Data and Information, January 2020, International Organization for Migrations, The UN Migration Agency, New York 2019 <https://displacement.iom.int/system/tdf/reports/FCR\%20Jan\%202020_ final.pdf $>$

$\checkmark$ NATO Glossary of Terms and Definitions nr AAP-6 (2019), Terrorism, NATO Standardization Agency

$\checkmark$ Osborne S., ISIS Commanders call for a coordinated wave of terror attacks in UK, Germany and France, <https://www.express.co.uk/ news/world/696404/ISIS-commanders-co-ordinated-wave-terror-attacksUK-Germany-France>

$\checkmark$ Oxford Learner's Dictionaries, Terrorism, $\quad<$ https://www.oxfordlearnersdictionaries.com/definition/english/terrorism>

$\checkmark$ Ozel H., Terrorist Tactics and their Destructions - a presentation delivered by the PfP Training Centre-Turkey Mobile Training Team (MTT) at the Romanian PfP Regional Training Centre in Bucharest, 2.04.2003

$\checkmark$ Security Council, Unanimously Adopting Resolution 2250 (2015), Urges Member States to Increase Representation of Youth in DecisionMaking at All Levels, Security Council Statement on 9.12.2015, <https://www.un.org/press/en/2015/sc12149.doc.htm>

$\checkmark$ Speech Geert Wilders for US Congressmen, Washington DC, Conservative Opportunity Society, 29.04.2015, <https://www.geertwilders.nl/94english/1921-speech-us-congressman-29042015>

$\checkmark$ Zeyno B., The Roots of Violent Islamist Extremism and Efforts to Counter It, Hearing Before The Committee on Homeland Security and Governmental Affairs United States Senate, One Hundred Tenth Congress Second Session, 10.07.2008, Washington 2009, pp. 119-124, <https://fas.org/irp/congress/2008_hr/roots.pdf > 